\title{
REDUCTION IN GROWTH OF WHITE SPRUCE AFTER OUT-PLANTING ${ }^{1}$
}

\author{
By R. E. MULLIN
}

\begin{abstract}
Several age-classes of nursery stock were sampled before and after the 1963 growing season by excavation of trees. Samples were also planted out and later excavated. Studies of several criteria to express check were made and leader length selected as the most practicable.

It is suggested that, by definition, a tree be considered in check until it has achieved a rate of terminal growth equivalent to that it would have attained in the next season in the nursery. Average leader lengths of unchecked trees are suggested for 2-0,3-0 and 2-2 stock. Check was found to reduce leader length by about $50 \%$ in the first year after outplanting. Other experiments indicate that the effect continued for ten years or more in many instances.

\section{INTRODUCTION}

The drastic reduction of the rate of growth of white spruce (Picea glauca (Moench) Voss) after planting has been reported previously (Mullin, 1963; White, 1960; Stiell, 1960). This report presents some quantitative information, with particular attention to growth during the first year after outplanting, and compares several criteria which might be used to show the amount of planting check. Smith and Walters (1963) have presented quantitative information on planting check in Douglas fir (Pseudotsuga menziesii Mirb.).
\end{abstract}

\section{Procedure}

Random samples of about 100 trees each were obtained from the 1-0 and 2-0 white spruce seedling beds and from the 2-1 and 2-2 transplant beds in the spring of 1963 from the Midhurst Nursery of the Ontario Department of Lands and Forests, about 60 miles north of Toronto. The following measurements were obtained for each tree, top length (ground to tip of terminal bud), root length (ground to tip of longest root, placed along ruler on laboratory bench), stem diameter ( $1 / 2$ inch above ground line), ovendry weight $\left(24\right.$ hours at $105^{\circ} \mathrm{C}$ ) and top-root ratio (in terms of oven-dry weight).

In addition to obtaining these samples for the laboratory, other samples of approximately 100 trees each were out-planted on the nursery. These trees were planted by the wedge method in scalps, on a moist sandy loam. The site had been cultivated one year before and contained a heavy growth of weeds.

${ }^{2}$ Contribution No. 64-15. Ontario Department of Lands and Forests, Research Branch, Maple, Ontario. 
At the end of the 1963 growing season, samples were again taken from each of the undisturbed nursery age-classes and from the field-planted stock. This permitted expression of the amount of growth in this season, from 1-0 to $2-0,2-0$ to $3-0,2-1$ to $2-2$, and $2-2-$ to $2-3$ for the undisturbed trees, and 2-0 to $2-0-1$ and $2-2$ to $2-2-1$ for the field-planted trees.

In addition to the foregoing, height measurements were also available for the control plots of several experiments in which white spruce had also been used in open or old-field planting.

\section{Results AND Discussion}

The data obtained from the Midhurst samplings are presented in two tables. Table 1 gives the pre-season and post-season sizes of the stock which developed from 1-0 to 2-0; and of the 2-0 which remained to become 3-0 in the nursery or which was outplanted to become $2-0-1$. Table 2 gives the pre-season and after-season sizes of the 2-1 which developed to 2-2; and of the 2-2 which remained in the nursery lines to become 2-3 or which was outplanted to become 2-2-1.

TABLE 1

Laboratory Measurements - Seedling Classes BEFORE AND AFTER 1963 GROWTH MIDHURST NURSERY

\begin{tabular}{|c|c|c|c|c|c|}
\hline & Spring & Fall & $\underset{2-0}{\text { Spring }}$ & $\begin{array}{l}\text { Fall } \\
3-0\end{array}$ & $\therefore \geq \underset{2-0-1}{\text { Fall }}$ \\
\hline Compartment & A-6 & A-6 & A-14 & A-14 & Field planted \\
\hline Top Length $\mathrm{cm}$. & 2.95 & $7.64(159)$ & 6.20 & $11.57(87)$ & $8.49(37)$ \\
\hline Root Length $\mathrm{cm}$. & 11.07 & $22.60(104)$ & 31.42 & $37.65(20)$ & $21.46(-)$ \\
\hline Stem Diameter $\mathrm{cm}$. & & 0.21 & 0.26 & $0.38(46)$ & $0.29(12)$ \\
\hline Oven-dry weight g. & 0.09 & $0.78(767)$ & 0.94 & $2.90(208)$ & $1.52(62)$ \\
\hline Top - root ratio & 2.35 & $1.87(-)$ & 1.94 & $2.41(24)$ & $2.81(45)$ \\
\hline Basis (no. of trees) & 100 & 100 & 100 & 98 & 84 \\
\hline
\end{tabular}

Figures in brackets are percentages of increase.

The auxiliary data, consisting of the average height of trees in the control plots of a number of experiments, is summarized in Table 3 .

a. Criteria of Check.

Weatherell (1953) noted the characteristic yellow to yellow-green colour associated with trees in check. Laing (1932) noted also that the needles were shorter than normal.

From the data in Tables 1 and 2 other criteria could be assessed which might be used to characterize check. Two of the criteria were promptly rejected; stem diameter, because it did not show any reduction in the case of transplants; and top-root ratio, because of opposing results in transplant and seedling classes. 
TABLE 2

\section{Laboratory Measurements - Transplant Classes BEFORE AND AFTER 1963 GROWTH MidHuRst NURSERY}

\begin{tabular}{|c|c|c|c|c|c|}
\hline & $\begin{array}{c}\text { Spring } \\
2-1\end{array}$ & $>\begin{array}{c}\text { Fall } \\
2-2\end{array}$ & $\begin{array}{c}\text { Spring } \\
2-2\end{array}$ & $\begin{array}{l}\text { Fall } \\
2-3 \\
\end{array}$ & $\underset{2-2-1}{\mathrm{Fall}}$ \\
\hline Compartment & $\mathrm{C}-4$ & C-4 & D-5 & D-5 & Field planted \\
\hline Top Length $\mathrm{cm}$. & 13.72 & $19.22(40)$ & 23.70 & $41.85(76)$ & $32.93(39)$ \\
\hline Root Length $\mathrm{cm}$. & 33.66 & $32.38(-)$ & 29.18 & $42.65(46)$ & $23.54(-)$ \\
\hline Stem Diameter $\mathrm{cm}$. & 0.44 & $0.57(30)$ & 0.59 & $0.72(22)$ & $0.72(22)$ \\
\hline Oven-dry weight g. & 3.98 & $8.17(105)$ & 9.26 & $18.86(104)$ & $14.94(61)$ \\
\hline Top - root ratio & 1.76 & $2.49(41)$ & 2.98 & $3.99(34)$ & $3.54(19)$ \\
\hline Basis (no. of trees) & 100 & 100 & 92 & 100 & 81 \\
\hline
\end{tabular}

Figures in brackets are percentages of increase.

TABLE 3

Average Heights of White Spruce OLD-FIELD PLANTINGS

(Control Plots of Several Experiments)

(All 2-2 at time of Planting)

\begin{tabular}{lccc}
\hline Location & $\begin{array}{c}\text { Years Since } \\
\text { Planting }\end{array}$ & $\begin{array}{c}\text { Basis } \\
\text { (No. of trees) }\end{array}$ & $\begin{array}{c}\text { Height } \\
\text { cm. }\end{array}$ \\
\hline Vivian Forest & 10 & 1516 & 210.2 \\
Kemptville Nursery & 10 & 881 & 157.0 \\
Kemptville Nursery & 10 & 1290 & 98.3 \\
Powassan & 5 & 488 & 33.8 \\
Parry Sound & 5 & 557 & 50.6 \\
Larose Forest & 5 & 757 & 76.5 \\
Larose Forest & 5 & 369 & 56.7 \\
Pakesley & 6 & 540 & 43.0 \\
Ganaraska Forest & 5 & 481 & 76.5 \\
\hline
\end{tabular}

Two of the other measurements, root length and oven-dry weight, would only be useful in the rare example where entire trees can be collected. The root lengths, an uncertain measurement, of the checked stock were shorter than before planting (2-2 to $2-2-1$ and $2-0$ to $2-0-1)$. This merely reflected the loss of part of the root system usually encountered in the planting of the species (Crossley, 1956; Mullin, 1963).

Comparisons in terms of oven-dry weight do give a picture of the extent of the change in growth rate. Considering seedling stock first, undisturbed seedlings showed an increase from $2-0$ to $3-0$, of about $208 \%$ oven-dry weight but when planted out this was reduced to about $62 \%$. Planting check had reduced growth to about one-fourth that of the undisturbed trees. 
Considering next the transplant stock (Table 2) the data showed an increase in oven-dry weight of undisturbed stock of about $104 \%,(2-2$ to 2-3). However, if the same stock was field planted (2-2 to 2-2-1), the growth increase was about $61 \%$. Planting check had reduced the growth, but much less in comparison with the reduction in seedling stock.

As oven-dry weight is a destructive measurement, the remaining criterion of increase in top length (height) was next considered. The increase in height of the seedlings in one season, from 2-0 to 3-0 was about $87 \%$. However, when the trees were outplanted the growth (2-0 to 2-0-1) only increased by $37 \%$, illustrating the onset of check. In the transplant stock the reduction was similar, from $76 \%$ for the undisturbed $2-3$ to $39 \%$ for the checked 2-2-1. In the transplant stock growing from 2-1 to 2-2 there was only a $40 \%$ increase in height. This illustrates that this stock is still showing check when its leader growth, averaging $5.50 \mathrm{~cm}$. is compared with the undisturbed 3-0 stock, a year younger showing $5.37 \mathrm{~cm}$. and the 2-3 stock, a year older, with $18.15 \mathrm{~cm}$.

It is concluded therefore, that current leader length in planted stock as compared with undisturbed stock is the most practicable criterion to use in expressing the degree of check.

\section{b. Standard of Check}

With a comparison of leader length in planted and undisturbed stock accepted as the criterion it is then necessary to have some standard to determine if an individual tree or percentage of a plantation is in check.

It is suggested that a reasonable definition could be established by stating that a tree remains in check until it has attained a leader length equivalent to that it would have attained in the nursery in the next growing season.

Leader lengths obtained in this 1963 study, for both the undisturbed and the checked trees are plotted in Fig. 1. From these growth curves the following standards are suggested for white spruce.

$\begin{array}{cc}\text { Age-classes } & \text { Expected leader } \\ \text { at planting } & \text { unchecked } \\ 2-0 & 5.5 \mathrm{~cm} . \\ 3-0 & 9.0 \mathrm{~cm} . \\ 2-2 & 18.0 \mathrm{~cm} .\end{array}$

These suggestions are based on limited information and would probably be subject to regional and seasonal adjustments. The basis used is a minimum because it can be seen that leader length increases at an increasing rate with age (Fig. 1) within the range of the measurements.

\section{c. Duration of Check in the Field}

The information of average height of the nine plantations in Table 3 does not permit study of the current leader length. However, if the proposed standard of $18 \mathrm{~cm}$. is projected and compared with the average heights, as in Fig. 2, it is obvious that check has continued for many years. It is possible that current growth may exceed $18 \mathrm{~cm}$., but not enough to have made up the loss in the early years after outplanting. 


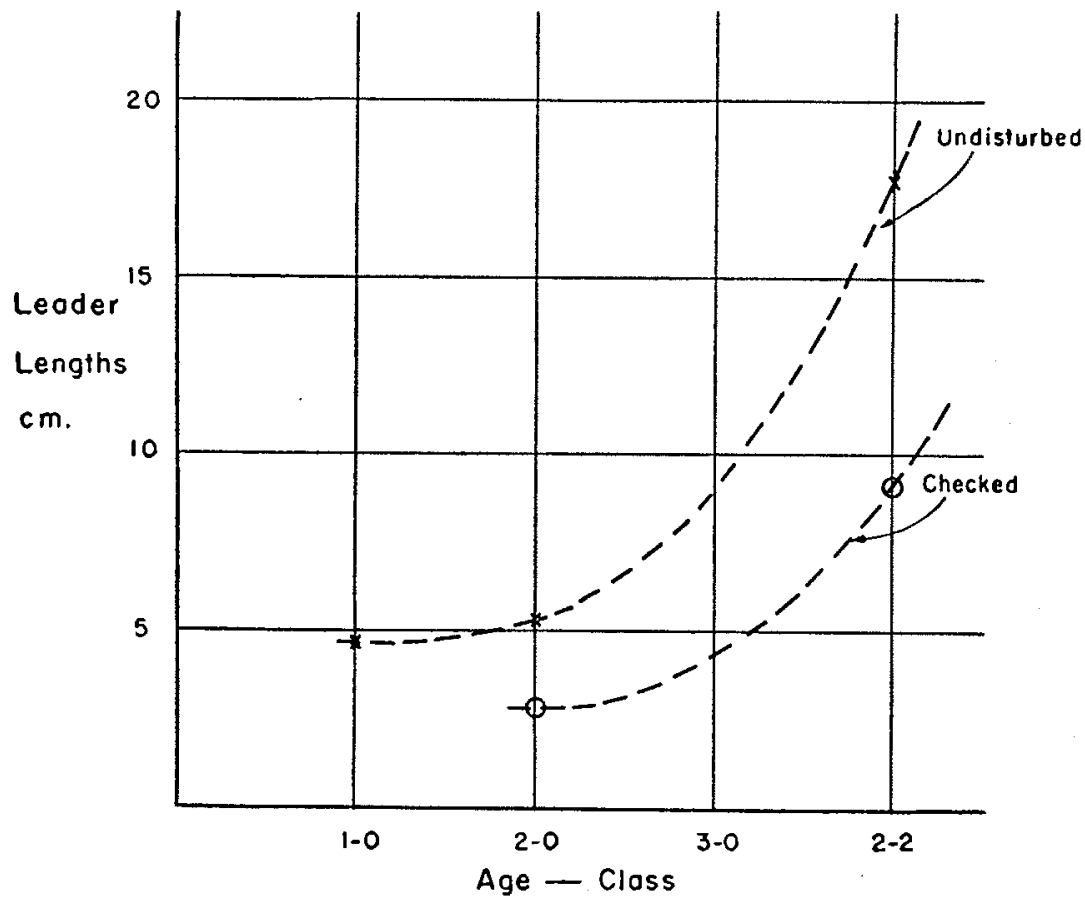

Figure 1. Average leader lengths of undisturbed and checked white spruce, Midhurst, 1963.

Although accurate measurements are not available it would appear from some observations that check may be more severe in the second and third year after outplanting than in the first.

\section{d. Comparison with Douglas fir}

Smith and Walters (1963) observed that Douglas fir 2-0 grew in the third year in the nursery at an average rate of 0.8 inches for each inch in height at the beginning of the growing season. The rate for white spruce in this experiment was about 0.87 inches for each inch in height at the beginning. This, of course, would vary with season, nursery soil condition, and other factors.

These authors found that even after careful outplanting the growth rate of the Douglas fir was about 0.16 inches for each inch of height at the time of planting; a reduction in growth rate of about $80 \%$. With white spruce the growth rate was reduced to 0.38 inches for the $2-0$ stock, a reduction in growth rate of only $57 \%$.

It would thus appear that the check of white spruce is not as severe as that of Douglas fir at the onset. However, the duration is of equal or greater importance and no comparative data are available. 


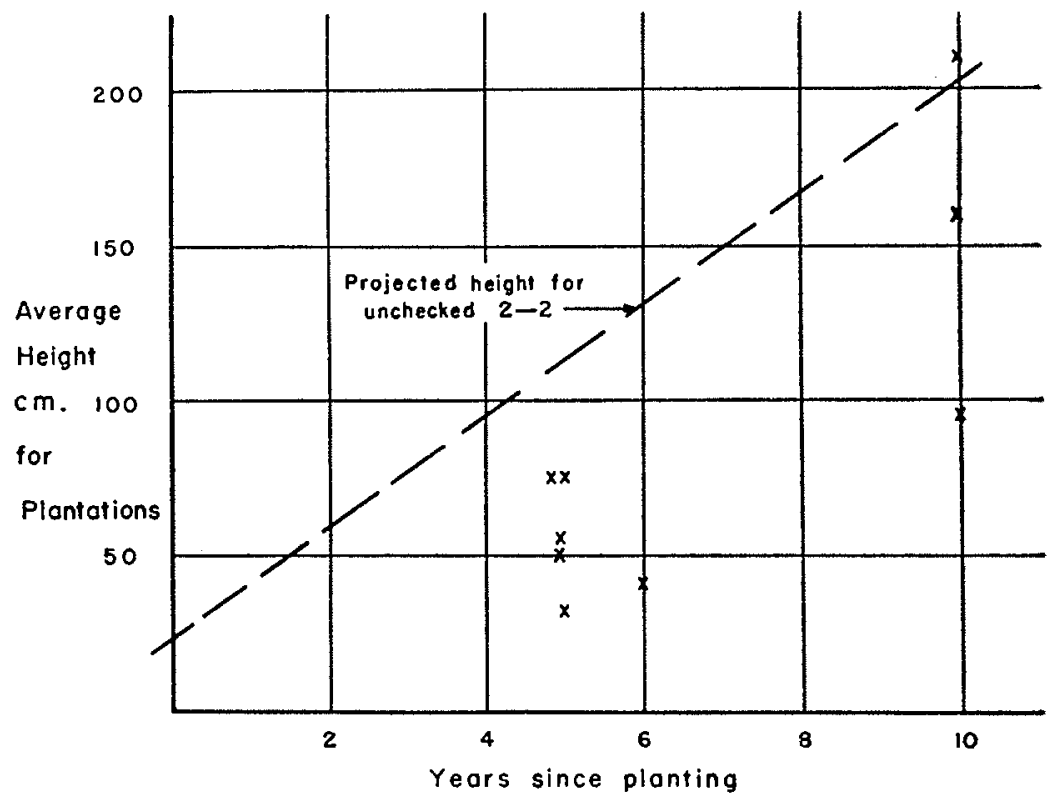

Figure 2. Averoge heights for several plontotions compored with extended rate of growth of unchecked 2-2 white spruce.

\section{CONCLUSIONS}

A comparison was made of several criteria which might be used to express check. It was found that root length, stem diameter and top-root ratio were unsuitable. Oven-dry weight was found satisfactory, but could only be used in cases where entire trees could be excavated. Leader length in the current growing season (rate of height growth, Smith and Walters, 1963) was confirmed as the most practicable criterion to express the degree of check. It is obviously the easiest to use to obtain a quantitative expression in the study of plantations.

It was found in this experiment that rate of growth of the leader was reduced in the first year following outplanting to $43-51 \%$ of that which would have been achieved in the nursery.

It was also suggested that average leader lengths might prove an adequate basis for expression of check by defining that a tree was in check until it achieved a rate of height growth equal to that it would have attained in the next season's growth if it had not been disturbed. Average leaders of $5.5 \mathrm{~cm}$. for $2-0$ stock, $9.0 \mathrm{~cm}$. for $3-0$ stock, and $18.0 \mathrm{~cm}$. for $2-2$ stock, are given as a guide but may be subject to regional and seasonal adjustments.

Study of several plantations showed that the effect of planting check was still important after 10 years, and much growth had been lost when judged even in these minimum terms.

References on page 502 


\section{CONCLUSIONS}

The stand models described here for Douglas fir and lodgepole pine permit rapid and inexpensive comparisons of a large number of alternatives related to initial spacing, and removal of trees by natural mortality or thinning. Similar models based upon measurements of open-grown trees of other species also could contribute much to improvement of forest management.

\section{Literature Cited}

BAILEY, G. R. 1964. Effect of competition on the growth and crown form of lodgepole pine. Univ. of B.C., Fac. of For., M.F. thesis, 128 p.

DAHMS, W. G. 1964. Gross and net yield tables for lodgepole pine. U.S.F.S., P.N.W. For. and Range Expt. Stn., Portland, Research Paper P.N.W.-8, 14 p.

NEWNHAM, R. M. 1964. The development of a stand model for Douglas fir. Univ. of B.C., Fac. of For., Ph.D. thesis, 201 p. Litho.

SMITH, J. H. G. 1963. Analysis of crown development can establish biological and economic limits to growth of trees and stands. Commonwealth For. Rev., 42(1): 27-33.

SMITH, J. H. G. 1964. Forecasting stand development from stem analysis. Proc. Soc. Amer. For., 1963, 31-4.

SMITH, J. H. G. and R. E. BREADON, 1964. Combined variable equations and volumebasal area ratios for total cubic foot volumes of the commercial trees of B.C. For. Chron. $40(2): 258-61$.

SMITH, J. H. G., KER, J. W. and J. CSIZMAZIA, 1961. Economics of reforestation of Douglas fir, western hemlock, and western red cedar in the Vancouver Forest District. Univ. of B.C. Fac. of For., For. Bull. No. 3, 144 p.

\section{Continued from page 493}

\section{REFERENCES}

CROSSLEY, D. I. 1956. The possibility of continuous planting of white spruce throughout the frost-free period. Canada Forestry Branch (For. Res. Div.) Tech. Note No. 32; 31 p. LAING, E. V. 1932. Studies on Tree Roots. Forestry Comm. London. Bull. No. 13. 72 p. + plates.

MULLIN, R. E. 1963. Planting check in spruce. For. Chron. 39 (3): 252-259.

SMITH, J. H. G. and J. WALTERS, 1963. Planting check (reduction in height growth) of planted Douglas fir seedling. Fac. of For., Univ. of British Columbia. Res. Notes No. 43.4 p.

STIELL, W. M. 1960. A co-operative experimental planting project in Ontario. Woodlands Review, Pulp \& Paper Magazine of Canada 61 (2): 3-6.

WEATHERELL, J. 1953. The checking of forest trees by heather. Forestry XXVI (1):37-40.

WHITE, D. P. 1960. Effect of fertilization and weed control on the establishment, survival and early growth of spruce plantations. 7th International Congress of Soil Science. Madison, Wisc., Transactions Vol. III. 355-362. 